\title{
How I approach membrane lung dysfunction in patients receiving ECMO
}

\author{
Bishoy Zakhary ${ }^{1 *}$ (D) Leen Vercaemst ${ }^{2}$, Phillip Mason ${ }^{3}$, Marta V. Antonini ${ }^{4,5}$, Roberto Lorusso $^{6}$ and Daniel Brodie ${ }^{7,8}$
}

\section{Introduction}

With improvements in circuit technology and expanding supportive evidence, extracorporeal membrane oxygenation (ECMO) use has grown rapidly over the past decade [1]. Advances in pump and membrane lung (ML) design have led to simpler and more efficient circuits. Circuitrelated complications, however, remain frequent and associated with considerable morbidity [2].

\section{Mechanisms of membrane lung dysfunction}

The ML is responsible for oxygen uptake and carbon dioxide removal. The non-biologic surface of the ML activates inflammatory and coagulation pathways with thrombus formation, fibrinolysis, and leukocyte activation [3-5] leading to ML dysfunction. Activation of coagulation and fibrinolysis can precipitate systemic coagulopathy or hemolysis, while clot deposition can obstruct blood flow [6, 7]. Additionally, moisture buildup in the gas phase and protein and cellular debris accumulation in the blood phase may contribute to shunt and dead-space physiology, respectively, impairing gas exchange $[8,9]$. These three categories-hematologic abnormalities, mechanical obstruction, and inadequate gas exchange-prompt the majority of ML exchanges.

\section{Membrane lung monitoring Hematologic profile}

Monitoring of hematologic variables, including coagulation and hemolysis labs, can help identify the development of an ECMO coagulopathy or hemolysis.

*Correspondence: bzakhary@gmail.com

${ }^{1}$ Division of Pulmonary and Critical Care Medicine, Oregon Health and Science University, Portland, OR, USA

Full list of author information is available at the end of the article

\section{Pressure monitoring}

The pressure drop across the ML $(\Delta \mathrm{P})$ is measured as (Additional file 1: Supplemental Figure):

$$
\Delta P=P_{\text {Pre }}-P_{\text {Post }}
$$

where $P_{\mathrm{Pre}}=$ pre-ML pressure, $P_{\text {Post }}=$ post-ML pressure.

As clot forms in the ML, increases in resistance $\left(R_{\mathrm{ML}}\right)$ are reflected as increases in $\Delta P$. To correct for changes in blood flow rate (BFR), monitoring of $\Delta \mathrm{P}$ normalized for $\mathrm{BF}$ rate $(\triangle P / \mathrm{BFR})$ more directly reflects $R_{\mathrm{ML}}$.

\section{Membrane lung gas transfer}

Applying the Fick principle across the ML, oxygen $\left(\mathrm{O}_{2}\right)$ transfer may be calculated as:

$$
V^{\prime} \mathrm{O}_{2}=\operatorname{BFR}\left(C_{\text {Post }} \mathrm{O}_{2}-C_{\text {Pre }} \mathrm{O}_{2}\right)
$$

where $V^{\prime} \mathrm{O}_{2}=\mathrm{O}_{2}$ transfer across the $\mathrm{ML}(\mathrm{mL} / \mathrm{min})$, $\mathrm{BFR}=$ blood flow rate $(\mathrm{L} / \mathrm{min}), C_{x} \mathrm{O}_{2}=\mathrm{O}_{2}$ content of (pre-/post-ML) blood (mL/L) for

$$
C_{x} \mathrm{O}_{2}=13.4 \cdot \mathrm{Hb} \cdot S_{x} \mathrm{O}_{2}+0.03 \cdot P_{x} \mathrm{O}_{2}
$$

where $\mathrm{Hb}=$ hemoglobin $(\mathrm{g} / \mathrm{dL}), S_{x} \mathrm{O}_{2}=\mathrm{O}_{2}$ saturation of (pre-/post-ML) blood, $P_{x} \mathrm{O}_{2}=\mathrm{O}_{2}$ partial pressure of (pre-/post-ML) blood (mmHg).

Measurement of $V^{\prime} \mathrm{O}_{2}$ provides an objective measure of oxygen transfer and can confirm ML dysfunction, when clinically indicated.

\section{Membrane lung dysfunction}

Prompt recognition of ML dysfunction is vital for safety, allowing for elective replacement in a controlled manner. On the other hand, replacement of an adequately functioning device-requiring temporary cessation of ECMO original author(s) and the source, provide a link to the Creative Commons licence, and indicate if changes were made. The images or other third party material in this article are included in the article's Creative Commons licence, unless indicated otherwise in a credit line to the material. If material is not included in the article's Creative Commons licence and your intended use is not permitted by statutory regulation or exceeds the permitted use, you will need to obtain permission directly from the copyright holder. To view a copy of this licence, visit http://creativecommons.org/licenses/by/4.0/. The Creative Commons Public Domain Dedication waiver (http://creativeco mmons.org/publicdomain/zero/1.0/) applies to the data made available in this article, unless otherwise stated in a credit line to the data. 
support-places the patient at unnecessary risk while consuming a limited and expensive resource.

Based on the pathophysiology of the ML, replacement may be required for one of three reasons: if there is (A) an associated hematologic abnormality, (B) an increasing obstruction to blood flow, or (C) inadequate gas exchange (Fig. 1).

\section{Hematologic abnormalities}

The presence of an ECMO coagulopathy, typified by elevated clotting times, hypofibrinogenemia, thrombocytopenia, and elevated D-dimer without alternate explanation raises concern for circuit-related coagulopathy (CRC). Alternatively, evidence of hemolysis with elevated plasma-free hemoglobin, without alternate explanation, is concerning for circuit-related hemolysis. In both cases, the diagnosis is presumptive and only confirmed when values normalize after circuit exchange [6].

\section{Obstruction to blood flow}

Increasing $\triangle P / B F R$ suggests increasing ML clot burden. As different MLs have different $R_{\mathrm{ML}}$, no cut-off values of $\triangle P$ define ML dysfunction and the trend should be carefully considered. A rapidly increasing $\Delta P$, even if not associated with reduced gas exchange efficiency, is often a harbinger of impending ML failure and should prompt consideration of ML exchange. When ML pressures are not measured, an increasing pump speed requirement to maintain a stable BFR can serve as a surrogate for increasing $\Delta \mathrm{P}$, with the caveat that pump preload and afterload also affect this relationship.

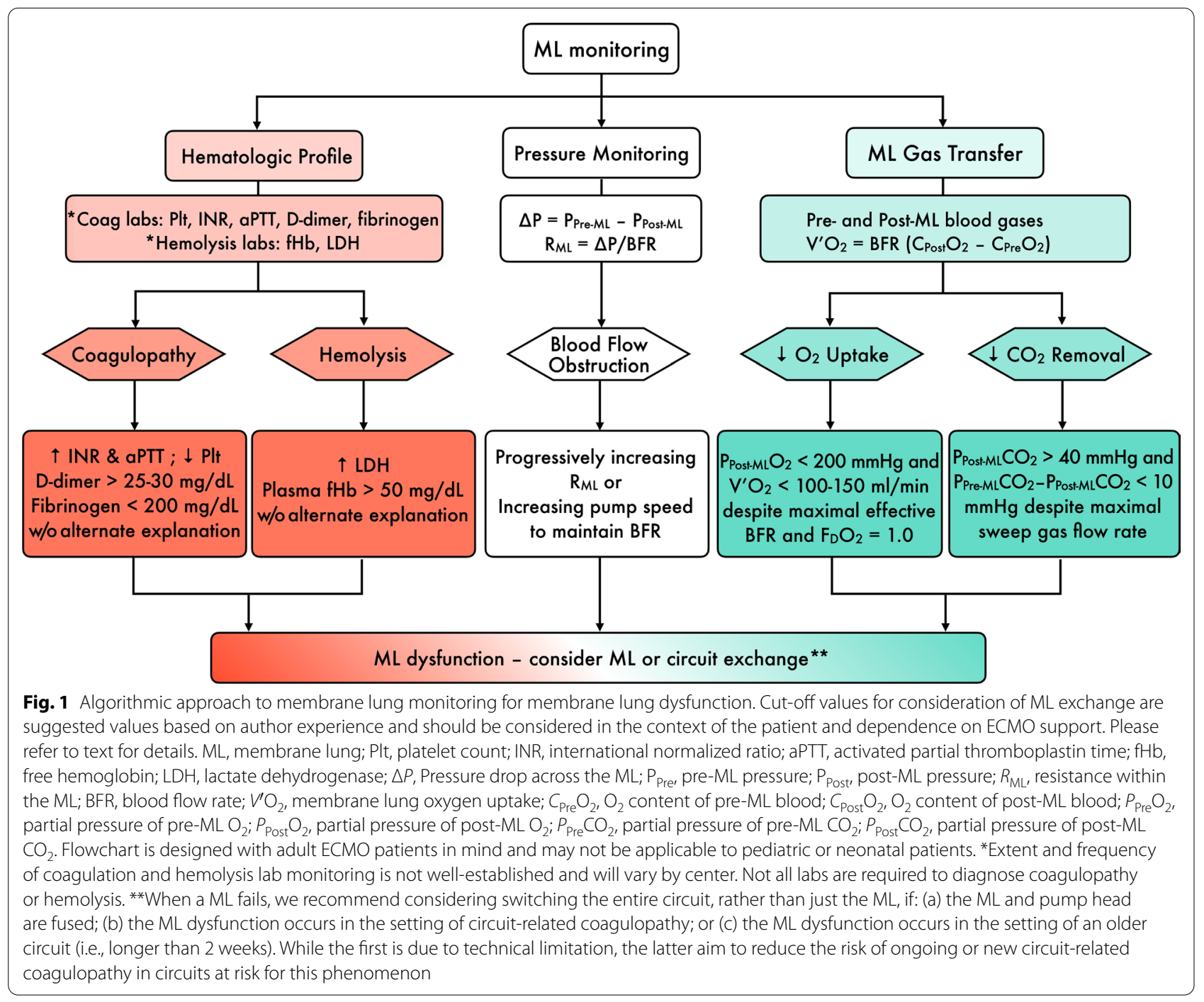




\section{Inadequate oxygen uptake}

Worsening oxygenation during ECMO should prompt quantification of oxygen transfer. When the ML is no longer able to meet patient oxygen demand, ML exchange is indicated. There are three important considerations in making this decision.

First, it is necessary that measured $V^{\prime} \mathrm{O}_{2}$ is truly a maximal value. If circuit BFR is low, for example, the blood will be fully saturated early in the ML path and reserve will exist for additional oxygen transfer as BFR is increased. Similarly, if $C_{\mathrm{Pre}} \mathrm{O}_{2}$ is artificially elevated, due to high recirculation fraction or impaired tissue extraction, or if the fraction of delivered oxygen in the sweep gas $\left(\mathrm{F}_{\mathrm{D}} \mathrm{O}_{2}\right)$ is below $100 \%$, the gradient driving oxygen transfer is reduced, and measured $V^{\prime} \mathrm{O}_{2}$ may not represent maximal capacity. As such, BFR should be sufficiently high that further increases do not increase arterial saturation, recirculation fraction should be minimized, and $\mathrm{ML} \mathrm{F}_{\mathrm{D}} \mathrm{O}_{2}$ set to $100 \%$ to ensure an accurate assessment of maximal $V^{\prime} \mathrm{O}_{2}$.

Second, though $P_{\text {Post-ML }} \mathrm{O}_{2}$ less than $200 \mathrm{mmHg}$ can suggest a failing ML [6], it is vital to calculate $V^{\prime} \mathrm{O}_{2}$ for confirmation. In the setting of low $C_{\mathrm{Pre}_{2}} \mathrm{O}_{2}$ or high circuit BFR, blood exiting the ML may not be fully saturated, with low $P_{\text {Post }} \mathrm{O}_{2}$, despite normal $V^{\prime} \mathrm{O}_{2}$. In this case, if the ML is exchanged, the patient is placed at risk without subsequent improvement in oxygen delivery.

Finally, no absolute values diagnose inadequate oxygen transfer and clinical context is important. In general, however, in a patient with hypoxemia and a ML with maximal $V^{\prime} \mathrm{O}_{2}<100-150 \mathrm{~mL} / \mathrm{min}$, ML exchange is typically indicated.

\section{Inadequate carbon dioxide clearance}

ML dysfunction can also manifest as inadequate $\mathrm{CO}_{2}$ clearance. Calculation of $V^{\prime} \mathrm{CO}_{2}$ is not typically performed as it varies in a nonlinear fashion with sweep gas flow rate and requires sampling $\mathrm{ML}$ exhaust $\mathrm{CO}_{2}$ [10]. However, persistent $P_{\text {Post-ML }} \mathrm{CO}_{2}$ greater than $40 \mathrm{mmHg}$ [6] and clearance of less than $10 \mathrm{mmHg}$ $\mathrm{PCO}_{2}$ between pre- and post-ML blood gases despite sweep gas flow rates of $10 \mathrm{~L} / \mathrm{min}$ or greater is suggestive of ML dysfunction and ML exchange should be considered.

\section{Sudden membrane lung failure}

While serial monitoring of the ML may identify markers of dysfunction and allow for elective exchange, acute ML failure is a potentially life-threatening event with unique considerations. Mechanisms to ensure optimal management are provided in the Additional file 2.

\section{Conclusion}

The decision to exchange a ML is complex and without clear guidelines. In this manuscript, we outline a physiologic approach to troubleshooting this common yet high risk event.

\section{Supplementary information}

Supplementary information accompanies this paper at https://doi. org/10.1186/s13054-020-03388-2.

Additional file 1. Membrane lung monitoring of pressure drop and oxygen transfer.

Additional file 2. Sudden Membrane Lung Failure.

\section{Abbreviations}

ECMO: Extracorporeal membrane oxygenation; ML: Membrane lung; COVID19: Coronavirus disease 2019; $\triangle P$ : Pressure drop across the $M L ; P_{\text {Pre }}:$ Pre-ML pressure; $P_{\text {Post }}$ : Post-ML pressure; $R_{\mathrm{ML}}$ : Resistance within the ML; BFR: Blood flow rate; $V^{\prime} \mathrm{O}_{2}$ : Membrane lung oxygen uptake; $\mathrm{CPre}_{2} \mathrm{O}_{2}: \mathrm{O}_{2}$ content of pre-ML blood; $\mathrm{C}_{\text {post }} \mathrm{O}_{2}: \mathrm{O}_{2}$ content of post-ML blood; $\mathrm{Hb}$ : Hemoglobin; $\mathrm{S}_{\text {pre }} \mathrm{O}_{2}$ : Fractional $\mathrm{O}_{2}$ saturation of pre-ML blood; $\mathrm{S}_{\text {post }} \mathrm{O}_{2}$ : Fractional $\mathrm{O}_{2}$ saturation of post-ML blood; $\mathrm{P}_{\text {Pre }} \mathrm{O}_{2}$ : Partial pressure of pre-ML $\mathrm{O}_{2} ; P_{\text {post }} \mathrm{O}_{2}:$ Partial pressure of post-ML $\mathrm{O}_{2} ;$ $V^{\prime} \mathrm{CO}_{2}: \mathrm{CO}_{2}$ clearance across the $\mathrm{ML} ; \mathrm{ExCO}$ : $\mathrm{ML}$ exhaust $\mathrm{CO}_{2} ; \mathrm{CRC}$ : Circuitrelated coagulopathy; $\mathrm{F}_{\mathrm{D}} \mathrm{O}_{2}$ : Membrane lung inlet oxygen fraction; $P_{\mathrm{Pre}} \mathrm{CO}_{2}$ : Partial pressure of pre- $\mathrm{ML} \mathrm{CO} \mathrm{CO}_{2} ; P_{\text {Post }} \mathrm{CO}_{2}$ : Partial pressure of post-ML $\mathrm{CO}_{2}$; Plt: Platelet count; INR: International normalized ratio; aPTT: Activated partial thromboplastin time; fHb: Free hemoglobin; LDH: Lactate dehydrogenase.

\section{Acknowledgements}

Not applicable.

\section{Authors' contributions}

BZ and DB conceived of the presented idea. All authors read and approved the final manuscript.

Funding

None.

Availability of data and materials

Not applicable.

Ethics approval and consent to participate

Not applicable.

\section{Consent for publication}

Not applicable.

\section{Competing interests}

Leen Vercaemst is consultant for Medtronic for conducting/coordinating EMEA region ECMO trainings. Dr. Lorusso is consultant for Medtronic and LivaNova and is on the medical advisory board for Eurosets (all honoraria are paid at the university). Dr. Brodie receives research support from ALung Technologies. He has been on the medical advisory boards for Baxter, Abiomed, Xenios and Hemovent. No other authors report conflicts of interest.

\section{Author details}

${ }^{1}$ Division of Pulmonary and Critical Care Medicine, Oregon Health and Science University, Portland, OR, USA. ${ }^{2}$ Department of Perfusion, University Hospital Gasthuisberg, Leuven, Belgium. ${ }^{3}$ Department of Surgery, Brooke Army Medical Center, San Antonio, TX, USA. ${ }^{4}$ General ICU, I Department of Anesthesia and Intensive Care, University Hospital of Parma, Parma, Italy. ${ }^{5}$ Department of Biomedical, Metabolic, and Neural Sciences, University of Modena and Reggio Emilia, Modena, Italy. ${ }^{6}$ Cardio-Thoracic Surgery Department, Heart and Vascular Centre, Maastricht University Medical Centre (MUMC), Cardiovascular Research Institute Maastricht (CARIM), Maastricht, The Netherlands. ${ }^{7}$ Columbia University College of Physicians and Surgeons, 
New York-Presbyterian Hospital, New York, USA. ${ }^{8}$ Center for Acute Respiratory Failure, New York-Presbyterian Hospital, New York, NY, USA.

Received: 14 September 2020 Accepted: 13 November 2020

Published online: 30 November 2020

\section{References}

1. Brodie D, Slutsky AS, Combes A. Extracorporeal life support for adults with respiratory failure and related indications: a review. JAMA. 2019;322(6):557-68.

2. Extracorporeal Life Support Organization. ECLS registry report: international summary. https://www.elso.org/Registry/Statistics/InternationalSu mmary.aspx. Accessed 4 August 2020.

3. Dornia C, Philipp A, Bauer S, Lubnow M, Muller T, Lehle K, et al. Analysis of thrombotic deposits in extracorporeal membrane oxygenators by multidetector computed tomography. ASAIO J. 2014;60(6):652-6.

4. Doyle AJ, Hunt BJ. Current understanding of how extracorporeal membrane oxygenators activate haemostasis and other blood components. Front Med (Lausanne). 2018;5:352.

5. Maul TM, Massicotte MP, Wearden PD. ECMO biocompatibility: surface coatings, anticoagulation, and coagulation monitoring. In: Firstenberg
MS, editor. Extracorporeal Membrane Oxygenation: Advances in Therapy. Croatia: IntechOpen; 2016. p. 30-5.

6. Lubnow M, Philipp A, Foltan M, Bull Enger T, Lunz D, Bein T, et al. Technical complications during veno-venous extracorporeal membrane oxygenation and their relevance predicting a system-exchange-retrospective analysis of 265 cases. PLoS ONE. 2014;9(12):e112316.

7. Hastings SM, Deshpande SR, Wagoner S, Maher K, Ku DN. Thrombosis in centrifugal pumps: location and composition in clinical and in vitro circuits. Int J Artif Organs. 2016:39(4):200-4.

8. Lehle K, Philipp A, Gleich O, Holzamer A, Muller T, Bein T, et al. Efficiency in extracorporeal membrane oxygenation-cellular deposits on polymethylpentene membranes increase resistance to blood flow and reduce gas exchange capacity. ASAIO J. 2008;54(6):612-7.

9. Epis $F$, Belliato M. Oxygenator performance and artificial-native lung interaction. J Thorac Dis. 2018;10(Suppl 5):S596-605.

10. Zakhary B, Sheldrake J, Pellegrino V. Extracorporeal membrane oxygenation and V/Q ratios: an ex vivo analysis of $\mathrm{CO}_{2}$ clearance within the Maquet Quadrox-iD oxygenator. Perfusion. 2020;35(1):29-33.

\section{Publisher's Note}

Springer Nature remains neutral with regard to jurisdictional claims in published maps and institutional affiliations.
Ready to submit your research? Choose BMC and benefit from:

- fast, convenient online submission

- thorough peer review by experienced researchers in your field

- rapid publication on acceptance

- support for research data, including large and complex data types

- gold Open Access which fosters wider collaboration and increased citations

- maximum visibility for your research: over $100 \mathrm{M}$ website views per year

At BMC, research is always in progress.

Learn more biomedcentral.com/submissions 